\title{
The Effect of Structured Academic Controversy on English Proficiency Level within Communicative Language Teaching Context
}

\author{
Reza Tavakoli \\ Department of English, University of Zanjan, Zanjan, Iran \\ Seyed Hesamuddin Aliasin \\ Department of English, University of Zanjan, Zanjan, Iran \\ Fariba Mobini \\ Department of English, University of Zanjan, Zanjan, Iran
}

\begin{abstract}
This study aimed at investigating the effect of Structured Academic Controversy (SAC) on English proficiency level of Iranian intermediate EFL learners within the Communicative Language Teaching (CLT) context. To this end, the Cambridge English Placement Test (CEPT) as the pre-test was administered to 90 EFL learners at Khayyam University of Mashhad, Iran. Based on the results and according to the test guidelines, only the intermediate EFL learners were selected as the final participants $(\mathrm{N}=60)$. Then, they were randomly divided into two groups of control and experimental, each group consisting of 30 subjects. Then, a ttest analysis was conducted to ensure that the two groups were not different in their English proficiency level before treatment. The experimental group was taught English based on a CLT syllabus supplemented by SAC techniques, whereas the control group received the same instruction but without being aided with the SAC techniques. After treatment, the participants received the same CEPT as the post-test. The t-test results for this test revealed a significant effect of SAC on the experimental group's performance on the post test, which means that SAC can play a role in EFL learners' English language proficiency improvement.
\end{abstract}

Index Terms - communicative language teaching (CLT), English proficiency level, structured academic controversy (SAC), EFL learners

\section{INTRODUCTION}

Not being specific to language learning and teaching, structured academic controversy (SAC) has been defined and/or exemplified by different researchers and scholars in various scientific disciplines (Claudia Khourey-Bowers, 2012; Johnson, 1997; Moore \& Zainuddin, 2003; Pappas, 2013). Some practitioners have employed SAC in their classroom or professional context. Bull (2007) used SAC in a graduate course in nursing. Nathan and Lee (2004) used SAC in the social studies classroom. In another attempt to employ SAC in a real context, Wright (2013) used SAC in an Advanced American Studies classroom. All of these researchers reported the positive effects of SAC on their learners' achievement.

However, when it comes to employing SAC in the field of language learning and teaching, the literature is evidently poor. In a position paper, Moore and Zainuddin (2003) advocate the use of SAC to improve critical thinking among English language learners. A rare research study involving SAC has been carried out by Hosseini (2009), in which he compared the effect of SAC with that of the competitive team-based learning (CTBL) on the overall proficiency of EFL college students. He reported that SAC contributed to CTBL in terms of improving learners' English proficiency. To the researchers' best knowledge, no other empirical study involving the implementation of SAC in EFL context has been reported in the related literature. As a result, further research is needed to fill this gap. This is what the present study has pursued to accomplish.

\section{LITERATURE REVIEW}

\section{A. Structured Academic Controversy (SAC)}

The Structured Academic Controversy was theorized and introduced by Johnson and Johnson (1997), who were working at University of Minnesota's Cooperative Learning Center. Khourey-Bowers (2012) states that:

Structured Academic Controversy (SAC) is a teaching approach in which students will research one or several points of view and then communicate their findings in a structured format. The goals of a SAC are for students to gain content knowledge about issues, appreciate and respect multiple viewpoints, and learn how to build consensus. SACs promote 
teaching about a controversy without requiring students to take a dualistic stance, straining classroom interactions between students with diverse views, or marginalizing students whose personal beliefs are different from those of the majority. (p.1)

According to Hess (2004), SAC promotes cooperative learning and cooperative method of research. Through a structured academic controversy lesson, learners are able to learn different aspects of a debatable issue- how to defend their position when supporting a particular aspect of that issue, and how to ventilate differing and/or contradictory views about an issue in an academic way. This method enables learners to formulate, classify, and comprehend ideas and information about a controversial issue. Moreover, it elicits informed responses from the learners.

Various step-by-step procedures have been suggested for the implementation of SAC. A more well-known step-bystep procedure is offered by Oxford learning institute of University of Oxford (2012). This institute proposes the following procedures for the smooth implementation of SAC in the classroom:

Students are placed in groups of four (two pairs). Each pair must: 1. Research and prepare a position on a given dilemma/controversial question; 2. Present and advocate their position; 3. Engage in open discussion, refuting the opposing position and rebutting attacks on their own position; 4. Reverse perspectives (forcefully present the other pair's position, including any arguments they believe the 'opposition' has failed to incorporate); 5.Synthesise and integrate the best evidence and reasoning into an agreed joint position. (p.1)

In the present study, the above procedures were customized and then used to implement SAC in the language classroom. (See "Procedure" section)

\section{B. Communicative Language Teaching (CLT)}

CLT approach arose as a reaction to the failure of the previous methods to develop sufficient communicative competence in the learners. Galloway (1993), for instance, states that learners are at "a loss to communicate in the culture of the language studied" (p.10). According to Widdowson (1989), the use of the target language in real-life situations would not be possible without the knowledge of the language and, more importantly, the ability to use that knowledge in real situations. CLT attempts to take all these issues into account, which were not sufficiently addressed by the previous approaches and methods. Richards (2006) states that:

Communicative language teaching can be understood as a set of principles about the goals of language teaching, how learners learn a language, the kinds of classroom activities that best facilitate learning, and the roles of teachers and learners in the classroom. (p.2)

What follows is an elaboration on the basic tenets of this approach.

1. The communicative approach $(C A)$

According to Ellis (1993), the communicative approach to language teaching is aimed at providing learners with ample opportunities to communicate readily in the target language. The natural outcome of this approach was a shift from form to meaning, with the main focus on the "learners' needs, motivation, characteristics, abilities, limitation, and resources" (Yalden, 1996, p.163). Indeed, what distinguishes communicative approach from other methods is the fact that apart from emphasis on grammar, CA maintains that if a learner is to be successful in language learning, s/he must acquire the communicative skills of a native speaker (Spolsky, 1989). Based on the characteristics of CA outlined above, a special type of language learning classroom, well-known as the learner-centered classroom, is required.

2. The communicative classroom

Below is the description of a number of features defining the communicative classroom. These features relate to the roles of the learning materials, students and teachers.

According to Richards and Rodgers (2006), if any type of material is to fulfill the requirements of the communicative approach, it should:

1. Improve students' abilities to interpret, express and negotiate.

2. Focus on comprehensible communication instead of grammatical form.

3. Provide learners with opportunities to stimulate their interest, intelligence and creativity.

4. Utilize texts and media of various types to enable students to improve their competence via different activities and tasks.

In a class in which CA is employed, Taylor (1983) states that students should do their best to acquire the target language, not by studying it, but by using it in a real way. This implies that students should take the responsibility of their own learning and that it is better to present language input to students in a simple language. Rodgers (2001) has compared students to negotiators and improvisers, meaning that each leaner is supposed to interact with other learners in search of information and feedback.

As for the role of the teacher, the teacher himself acts like a negotiator. Just as students provide feedback to each other, the teacher also gives them feedback, and sometimes may even receive feedback from students. Teachers provide solutions and assistance where necessary (Gutierrez, 2005). Teachers act like a guide, a planner, a facilitator of learning, a consultant, and a monitor. Thus, a communicative class is far from being a teacher-centered class.

Another description of the roles of teachers and learners is offered by Richards (2006). He states that:

Learners now had to participate in classroom activities that were based on a cooperative rather than individualistic approach to learning. Students had to become comfortable with listening to their peers in group work or pair work tasks, rather than relying on the teacher for a model. They were expected to take on a greater degree of responsibility for their 
own learning. And teachers now had to assume the role of facilitator and monitor. Rather than being a model for correct speech and writing and one with the primary responsibility of making students produce plenty of error-free sentences, the teacher had to develop a different view of learners' errors and of her/his own role in facilitating language learning. (p.5)

\section{The communicative activities}

What matters most in providing students with situations to use the target language is to employ communicative activities. According to Tait (2001), these are such activities that are fluency-based and promote both meaningful and purposeful interactions among L2 learners. In such interactions, students are both the receivers and providers of information, exchanging feedback with each other, etc. (Gower, Walter \& Phillips, 1995; Harmer, 2003).The basic requirement for such situations and activities to occur is that the class should be student-oriented and activities must be geared to be, in Richards and Rodgers's (1982) words, "interactive, authentic, purposive, and contextualized" (p.201). According to the Longman English Language Teaching (2007), the following characteristics help define a useful communicative activity:

1. Creating a desire in the learner to communicate.

2. Being built upon a communicative purpose

3. Concentrating on language content rather than forms

4. Variation in the use of target language

5. Minimizing the degree of teacher intervention.

6. Avoiding simplifying the materials.

Richards (2006) enumerated seven CLT activities, some of which are as follows:

1. Information-gap activities such as jig-saw activities. Richards (2006) explains jig-saw activity in the following terms:

the class is divided into groups and each group has part of the information needed to complete an activity. The class must fit the pieces together to complete the whole. In so doing, they must use their language resources to communicate meaningfully and so take part in meaningful communication practice. The following are examples of jigsaw activities. (p.19)

2. Task-completions activities in which learners have to rely on their own linguistic knowledge to accomplish a task. e.g. puzzles, map-reading, etc.

3. Role play activities in which learners are asked to adopt roles and communicate with each other, in way that simulates real-life situations.

4. Information-gathering activities in which learners should collect information by means of survey, interview, etc, provided that they use the target language to carry out such activities.

Having defined and exemplified CLT activities, Richards (2006) highlights that

Most of the activities discussed reflect an important aspect of classroom tasks in CLT, namely that they are designed to be carried out in pairs or small groups. Through completing activities in this way, it is argued, learners will obtain several benefits: 1 . They can learn from hearing the language used by other members of the group. 2 . They will produce a greater amount of language than they would use in teacher-fronted activities. 3. Their motivational level is likely to increase. 4. They will have the chance to develop fluency. Teaching and classroom materials today consequently make use of a wide variety of small-group activities. (p.20)

Given the importance of the learner's ability to use the target language communicatively, this study sought to explore the role of the SAC in developing EFL learners English language proficiency. For this purpose, the following research question was posed in order to test the corresponding hypothesis.

\section{RESEARCH QUESTIONS AND HYPOTHESIS}

The present study was an attempt to answer the following research question:

Does Structured Academic Controversy (SAC) within the CLT context affect Iranian intermediate EFL learners' English proficiency?

The following null hypothesis is assumed for the above question:

Structured Academic Controversy (SAC) within the CLT context does not affect Iranian intermediate EFL learners' English proficiency.

\section{METHOD}

\section{A. Participants}

The sample of the present study consisted of 60 (40 females and 20 males) Iranian intermediate EFL learners, selected out of a total number of 90 EFL learners at Khayyam University of Mashhad, Iran. They were all sophomores, aging from 18 to 20 . They were homogenized across the intermediate language proficiency level based on the results of the proficiency test described below.

\section{B. Instrumentation}




\section{Cambridge English Placement Test (CEPT)}

This test was used to homogenize the subjects in terms of English Proficiency. It consists of 25 items to be answered in 20 minutes. The items move from the easiest to the most difficult. Based on the test manual, those scores falling somewhere from 13 to 17 out of 25 are considered intermediate. According to this guideline, 60 intermediate participants were extracted from the total number of 90 learners. The Cronbach's $\alpha$ for the test was calculated at 0.823 , which indicated a high reliability index.

\section{Procedures}

Initially, the CEPT as the pre-test was administered to 90 EFL learners. The results were used to screen the subjects for intermediate language proficiency level. Thus, 60 intermediate EFL learners were selected as mentioned earlier. Then, the participants were randomly divided into two groups of experimental and control, each with 30 members. As for treatment, the experimental group was taught English based on a CLT-oriented syllabus supplemented by the SAC techniques, whereas the control group within the same CLT context did not receive the SAC techniques. The participants in the experimental group were required to discover how English can be better learned from the viewpoints of different scholars and practitioners such as linguists, language teachers and psychologists

The following step-by-step procedure was employed to implement SAC techniques:

(1) The class was divided into 3 groups. Students had to find their relevant materials from online and offline resources (i.e. internet, libraries, etc). The EFL learners in each group were supposed to study their own materials and get prepared to play the roles of linguists, language teachers and psychologists. They were encouraged to remain openminded and value the findings of other groups and what they contribute to the discussion.

(2) Each group wrote a summary of their findings in the respective scientific field. It was recommended that the summary be typed on $2-3$ pages. A representative of each group was supposed to read the summary of the group in the class. The other two groups had to listen, comment and ask questions.

(3) The representative was expected to be ready to answer any questions about his/her group's findings.

(4) At the end of the class session, all three groups were asked to discuss how the perspectives of linguists, language teachers and psychologists might complement each other.

It goes without saying that the teacher of this class was adequately instructed how to implement the above-mentioned elaborate procedure. Finally, the researchers administered the CEPT test again as the posttest to explore any differences between the experimental and control groups' English language proficiency after treatment.

\section{Results of Data Analysis}

\section{A. T-test Results for Homogeneity of Groups}

An independent-samples t-test was used to compare the two groups' performance on the CEPT test (pretest) in order to ensure the homogeneity of both groups in terms of English language proficiency level before treatment. The results revealed no significant difference between the mean scores of the control group ( $\underline{\mathrm{M}}: 14.50, \underline{\mathrm{SD}}$ : 1.10), and experimental group (M: 15.40, SD: 0.67; $\mathrm{t}(47.9)=3.8-, \mathrm{p}=0.071)$. Thus both groups were homogenous regarding their English proficiency. Table 1 and Table 2 below report the descriptive statistics and t-test results of the analysis, respectively.

TABLE 1.

GROUP STATISTICS FOR CONTROL AND EXPERIMENTAL GROUP (PRE-TEST)

\begin{tabular}{llllll}
\hline \multicolumn{5}{c}{ GROUP STATISTICS FOR CONTROL AND EXPERIMENTAL GROUP (PRE-TEST) } \\
\hline \multirow{2}{*}{$\begin{array}{l}\text { English Proficiency of Learners } \\
\text { Before Treatment }\end{array}$} & Group & $\mathrm{N}$ & Mean & Std. Deviation & Std. Error Mean \\
\cline { 2 - 7 } & Experimental & 30 & 14.50 & 1.10 & 0.20 \\
\hline
\end{tabular}

TABLE 2.

INDEPENDENT-SAMPLES TEST FOR CONTROL AND EXPERIMENTAL GROUP (PRE-TEST)

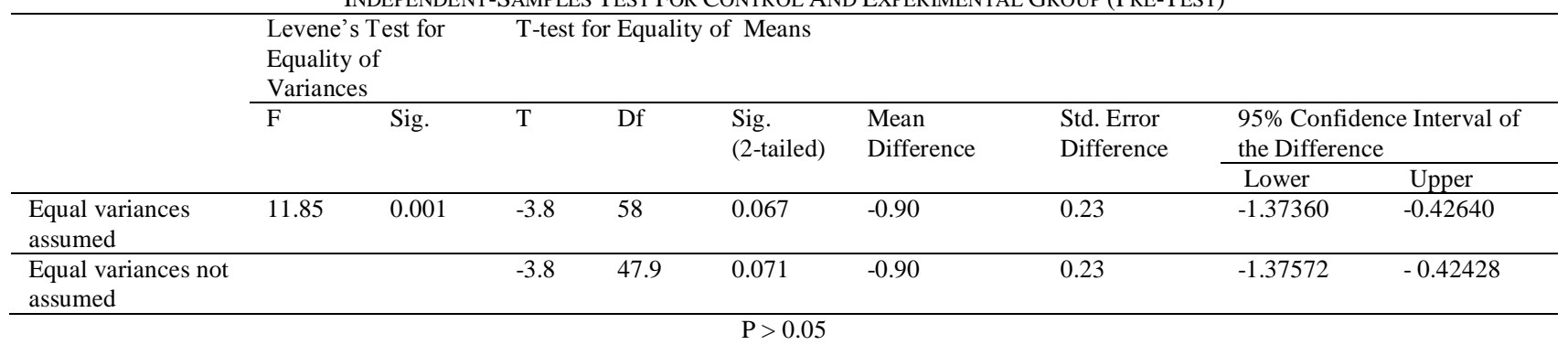

\section{B. Findings for the Research Question}

In order to investigate the research question of the study, the researchers conducted another independent-samples Ttest analysis to study any difference between the control and experimental groups' performance on the CEPT after treatment (posttest). The results of t-test indicated a significant difference between the control group $(\underline{M}=14.96, \underline{S D}=$ 
1.06), and the experimental group $[\underline{\mathrm{M}}=20.93, \underline{\mathrm{SD}}=4.17 ; \mathrm{t}(32.76), \mathrm{p}=-7.58$,$] , indicating that \mathrm{SAC}$ did have a positive effect in improving the experimental group's English proficiency. The magnitude of the difference, i.e., the effect size, was large (eta square $=0.49$ ), based on Cohen's (1988) ratings (as cited in Pallant, 2001, p.175). This means that about 49 percent of the variance in the post-test is explained by the usage of SAC. The results for the analysis are given in Table. 3 and Table. 4

TABLE 3.

Group Statistics For THE IMPACT OF SAC ON ENGLish LANGUAGE PROFICIENCY (Post-TeST)

\begin{tabular}{llllll}
\hline & Group & $\mathrm{N}$ & $\mathrm{Mean}$ & Std. Deviation & Std. Error Mean \\
\hline English Proficiency of Learners & Control & 30 & 14.96 & 1.06 & 0.19 \\
\cline { 2 - 7 } Before Treatment & Experimental & 30 & 20.93 & 4.17 & 0.76 \\
\hline
\end{tabular}

TABLE 4.

INDEPENDENT-SAMPLES TEST FOR THE IMPACT OF SAC ON ENGLISH LANGUAGE PROFICIENCY (POST-TEST)

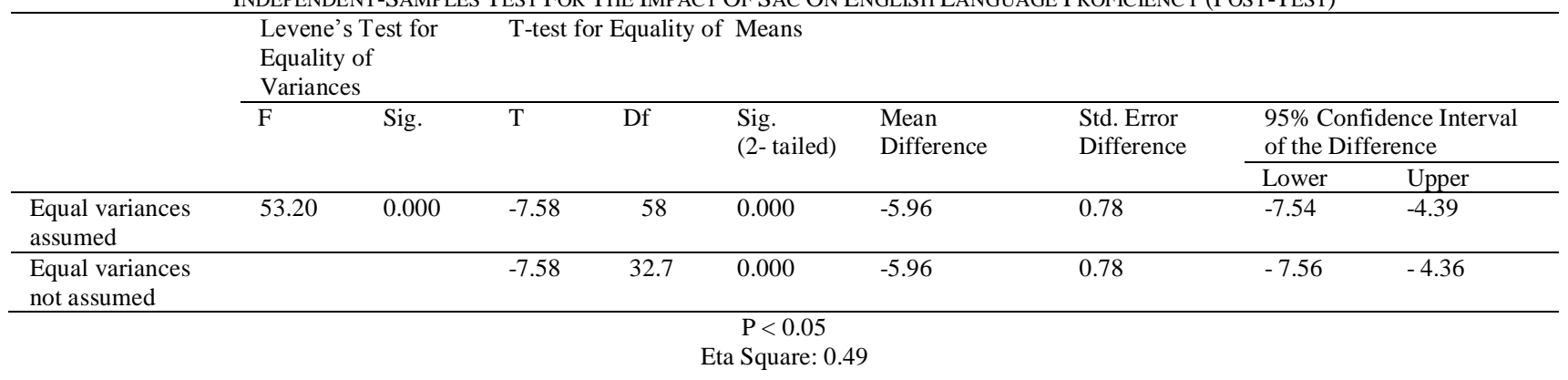

\section{DISCUSSION}

The finding of the study that SAC can have a positive effect on EFL learners' English proficiency is in line with the findings of Bull (2007) Nathan and Lee (2004), and Wright (2013) who also found the facilitative effects of SAC in their respective fields of study. The reason why the participants in the experimental group outperformed their counterparts in the control group regarding performance on the language proficiency posttest may be accounted for in several ways.

Firstly, during the study, the experimental group had the opportunity to read various English-language texts such books, magazines, articles, etc, both online and offline. Reading such a wide range of resources seems to have improved experimental group students' reading ability and vocabulary size. Secondly, they had the opportunity to write a summary of their findings, present and discuss them orally at each class session. This, in turn, provided them with an opportunity to practice their writing ability, speaking ability and listening skill in an organized way offered by SAC.

Nevertheless, the finding of the present study is not to be taken as conclusive. It could be fruitfully replicated by other researchers to further explore any possible effect of SAC in other relevant contexts with different participants. Further research can also be conducted to investigate the effect of SAC on individual characteristics such as anxiety, self-esteem, etc. Any research in this area can improve our understanding of the psychological impact of SAC on L2 learners.

\section{CONCLUSIONS AND IMPLICATIONS}

The finding of the present study may carry several pedagogical implications. First of all, the study contributes to the current situation of language learning and teaching in an Iranian context and potentially beyond, encouraging a careful implementation of SAC in any context in which CLT is practiced. The study also suggests that CLT, despite its widespread popularity, is not an absolute perfection that cannot be further enhanced. This study is an example of how to increase the functionality of CLT. Another implication is that the role of learners is of utmost importance. Although CLT, even without the implementation of SAC, is by itself a learner-centered approach, the study suggests that the role of learners through the implementation of SAC can become even far more conspicuous. It is recommended that the EFL teachers should make learners familiar with SAC through some explicit explanations and warm-up activities similar to SAC. Therefore, learners become affectively and cognitively better prepared to cope with what SAC demands.

\section{REFERENCES}

[1] Bull, M. J. (2007). Using structured academic controversy with nursing students. US National Library of Medicine. 32(5):21822. http://dx.doi.org/10.1097/01.NNE.0000289386.21631.c3.

[2] Cohen, J. (1988). Statistical power analysis for the behavioral sciences. Hillsdale, NJ: Erlbaum.

[3] Ellis, R. (1993). The structural syllabus and second language acquisition. TESOL Quarterly, 27(1), 91-113. http://dx.doi.org/10.2307/3586953. 
[4] Galloway, A. (1993). Communicative language teaching: An introduction and sample activities. ERIC Clearing house on Languages and Linguistics Washington, DC. (ERIC Document Reproduction Service No. ED357642). http://www.ericdigests.org/1993/sample.htm. (Access May 2015).

[5] Gower, R., Walter, S. \& Phillips, D. (1995). Teaching practice handbook. Oxford: Heinemann.

[6] Gutierrez, D. G. (2005). Developing oral skills through communicative and interactive tasks. Profile Issues in Teachers' Professional Development, ISSN 1957-0790 version impersa. Bogota: Institucion Educativa Distrital Britalia.

[7] Harmer, J. (2003). Popular culture, methods, and context. ELT Journal 57 (3), 288-294. http://dx.doi.org/10.1093/elt/57.3.288.

[8] Hess, B. (2004). Structured academic controversy. http://podcasts.shelbyed.k12.al.us/sspears/structured-academiccontroversy.(Accessed May 2015).

[9] Hosseini, M.H. (2009). A study of the effects of competitive team-based learning and structured academic controversy on the language proficiency of Iranian EFL college seniors. International Journal of Adult Vocational Education and Technology (IJAVET), 3(4), 54-69. http://dx.doi.org/10.4018/javet.2012100105.

[10] Johnson, D.W., Johnson, R.T. \& Smith, K.A. (1997). Academic controversy: enriching college instruction through intellectual conflict. http://www.ericfacility.net/data bases/ERIC_Digests/ed409828.html. (Accessed May 2015).

[11] Khourey-Bowers, C (2012). Structured academic controversy. http://serc.carleton.edu/sp/library/sac/index.html. (Accessed May 2015).

[12] Longman English Language Teaching. (2007). What is communicative methodology? http://www.longman.com. (Accessed in May 2015).

[13] Moore, R.A., Zainuddin, H. (2003). Enhancing critical thinking with structured controversial dialogues. The Internet TESL Journal. 9 (6), 45-51.

[14] Nathan, E., Lee, C.K. (2004). Using structured academic controversies in the social studies classroom. Teaching and Learning, 25(2) .pp. 171-188.

[15] Oxford Learning Institute of University of Oxford. (2012). Exploring dilemmas through Structured academic controversy. https://www.learning.ox.ac.uk/media/global/wwwadminoxacuk/localsites/oxfordlearninginstitute/documents/supportresources/l ecturersteachingstaff/developmentprogrammes/Aca dControversy.pdf (Accessed May 2015).

[16] Pallant, J. (2001). The SPSS survival manual: A step-by-step guide to data analysis using SPSS for Windows (version 10). St Leonards, NSW: Allen \& Unwin.

[17] Pappas, P. (2013). How to teach structured academic controversy. http://www.peterpappas.com/2013/06/how-to-teachstructured-academic-controversy.html (Accessed May 2015)

[18] Richards, J. C. T. S. \& Rodgers, T. S. (1982). Method: Approach, design, and procedure. TESOL Quarterly, 16(2), $153-168$. http://dx.doi.org/10.2307/3586789.

[19] Richards, J. C. T. S. \& Rodgers, T. S. (2006). Approaches and methods in language teaching. New York: Cambridge University Press. http://dx.doi.org/10.1017/CBO9780511667305.

[20] Richards, J. C. (2006). Communicative Language Teaching Today. New York: Cambridge University Press.

[21] Rodgers, T. S. (2001). Language teaching methodology. Online Resources: Digests. Issue Paper. November 25, 2007, www.cal.org/Resources/Digestrodgers.html. (Accessed May 2015).

[22] Spolsky, B. (1989). Communicative competence, language proficiency, and beyond. Applied Linguistics, $10(2), 138152$. http://dx.doi.org/10.1093/applin/10.2.138.

[23] Tait, S. (2001). Ingredients for successful communicative tasks. http://www.tefl.net/esl-articles/esl communicative-tasks.htm. (Accessed May 2015).

[24] Taylor, B. P. (1983). Teaching ESL: Incorporating a communicative, students-centered component. TESOL Quarterly, 17(1), 69-85. http://dx.doi.org/10.2307/3586425.

[25] Widdowson, H. G. (1989). Knowledge of language and ability for use. Applied Linguistics, 10(2), $128-137$. http://dx.doi.org/10.1093/applin/10.2.128.

[26] Wright, S. (2013). Application of differentiated instruction structured Academic controversy (SAC) Lesson. http://sarahwright.wmwikis.net/file/view/Differentiated\%20Instruction\%20SAC.pdf (Accessed May 2015).

[27] Yalden, J. (1996). The communicative syllabus: Evolution, design and implementation. New York: International Book Distributors Ltd.

Reza Tavakoli is holder of Master of Arts in English Language Teaching (ELT). He obtained his MA from University of Zanjan, Iran in 2015.His research interests include, but not limited to, quantitative research in language learning strategy use, eclectic approach to language teaching, enhancing teaching methodologies, material development.

Seyed Hesamuddin Aliasin is an assistant professor of TEFL at the University of Zanjan, Iran. He finished his undergraduate studies at Ferdowsi University of Mashhad, majoring in English language and literature. He continued his graduate studies at Allamehtabatabaee University of Tehran, where he got his MA degree in TEFL. Finally, he completed his studies at the University of Tehran, obtaining his PhD in TEFL. He presents his research findings at conferences and publishes articles. His main research interests include applied linguistics as well as issues in SLA, language teaching pedagogy, language awareness, language asse ssment, etc.

Fariba Mobini is an assistant professor of TEFL at the University of Zanjan, Iran. She holds a PhD in English language teaching. She has taught several English courses at undergraduate and graduate level, and has supervised numerous MA theses. 